Article

\title{
Crosslinked Sulfonated Polyphenylsulfone-Vinylon (CSPPSU-vinylon) Membranes for PEM Fuel Cells from SPPSU and Polyvinyl Alcohol (PVA)
}

\author{
Je-Deok Kim ${ }^{1,2,3, *}$, Satoshi Matsushita ${ }^{1}$ and Kenji Tamura ${ }^{3}$ \\ 1 Polymer Electrolyte Fuel Cell Group, Global Research Center for Environmental and Energy Based on \\ Nanomaterials Science (GREEN),Tsukuba Ibaraki 305-0044, Japan; satoshi.matsushita@agc.com \\ 2 Hydrogen Production Materials Group, Center for Green Research on Energy and Environmental Materials, \\ Tsukuba Ibaraki 305-0044, Japan \\ 3 Functional Clay Materials Group, Research Center for Functional Materials, National Institute for Materials \\ Science (NIMS), 1-1 Namiki, Tsukuba, Ibaraki 305-0044, Japan; Tamura.Kenji@nims.go.jp \\ * Correspondence: kim.jedeok@nims.go.jp; Tel.: +81-29-860-4764; Fax: +81-29-860-4984
}

Received: 3 June 2020; Accepted: 14 June 2020; Published: 16 June 2020

\begin{abstract}
A crosslinked sulfonated polyphenylsulfone (CSPPSU) polymer and polyvinyl alcohol (PVA) were thermally crosslinked; then, a CSPPSU-vinylon membrane was synthesized using a formalization reaction. Its use as an electrolyte membrane for fuel cells was investigated. PVA was synthesized from polyvinyl acetate (PVAc), using a saponification reaction. The CSPPSU-vinylon membrane was synthesized by the addition of PVA (5 wt\%, $10 \mathrm{wt} \%, 20 \mathrm{wt} \%)$, and its chemical, mechanical, conductivity, and fuel cell properties were studied. The conductivity of the CSPPSU-10vinylon membrane is higher than that of the CSPPSU membrane, and a conductivity of $66 \mathrm{mS} / \mathrm{cm}$ was obtained at $120^{\circ} \mathrm{C}$ and $90 \% \mathrm{RH}$ (relative humidity). From a fuel cell evaluation at $80^{\circ} \mathrm{C}$, the CSPPSU-10vinylon membrane has a higher current density than CSPPSU and Nafion 212 membranes, in both high $(100 \%$ $\mathrm{RH})$ and low humidification $(60 \% \mathrm{RH})$. By using a CSPPSU-vinylon membrane instead of a CSPPSU membrane, the conductivity and fuel cell performance improved.
\end{abstract}

Keywords: PPSU; SPPSU; PVA; CSPPSU-vinylon; PEMFCs

\section{Introduction}

In order to realize a low-carbon society that includes highly efficient energy systems which make effective use of renewable energy, economically sustainable growth, environmental protection, and energy security are required. Energy conversion/storage devices-such as fuel cells, water electrolysis, secondary batteries, and solar cells_-are core technologies for building a low-carbon society. In order to produce these devices safely and with high performances, their constituent materials must have high performances. Polymer electrolyte membranes for proton exchange in fuel cells are required for polymer electrolyte membrane fuel cells (PEMFCs), and polymer electrolyte membrane water electrolysis (PEMWE), and Nafion membranes mainly using perfluorosulfonic acid (PFSA) ion exchange resins, are often used. Nafion membranes have high proton conductivities and excellent chemical stabilities, and have been used in both mobile and stationary fuel cells [1,2]. However, the performance of these fuel cells suffers from the deterioration of their mechanical properties, due to thinning of the electrolyte membrane. In addition, higher operating temperatures are required to improve both the glass transition temperature $\left(T_{\mathrm{g}}\right)$ and the proton conductivity at high temperatures. At the same time, research on hydrocarbon-based electrolytes, instead of fluorine-based electrolytes, has been conducted. Non-fluorine-based electrolytes are low cost materials, have high $T_{\mathrm{g}}$ values, and have been studied for many years. However, their performances and chemical stabilities, which are lower 
than those of fluorine-based ones, have been the biggest obstacles towards their practical use. Thus, materials for proton exchange electrolytes with higher performances are still needed.

The drawbacks of PFSA membranes have prompted research into alternative membranes. Various aromatic polymer ionomer membranes are being actively investigated. Sulfonated polyphenylsulfone (SPPSU) [3-20], sulfonated polyetheretherketone (SPEEK) [21-32], sulfonated polysulfone (SPSU) [33-38], sulfonated polyphenylene sulfone (SPPS) [39], sulfonated polyphenylene (SPP) [40], sulfonated polyethersulfone (SPES) [41,42], sulfonated polyimide (SPI) [43-45], sulfonated polyphenylene oxide (SPPO) [46], and polybenzimidazole (PBI) $[47,48]$ are attracting special interest.

We are developing a crosslinked sulfonated polyphenylsulfone (CSPPSU) membrane using the sulfonation of the polyphenylsulfone (PPSU) polymer, which has an excellent thermal stability, high chemical resistance, and is low cost $[3,5,6,19,20]$. According to a fuel cell evaluation using the CSPPSU membrane, the membrane could be used for $4000 \mathrm{~h}$ [19]. However, compared to fluorine-based electrolyte membranes, hydrocarbon-based CSPPSU membranes are still insufficient in terms of high performances and high durabilities in fuel cells. It is necessary to further improve the performance and durability of SPPSU membranes. In this study, we prepared a CSPPSU-vinylon membrane, which has a higher performance than both CSPPSU and Nafion212 membranes. Vinylon was obtained using a formalization reaction with polyvinyl alcohol (PVA), and PVA was obtained by the saponification of polyvinyl acetate (PVAc). Crosslinked SPPSU-vinylon membranes from the SPPSU and PVA, were obtained using thermal crosslinking and a formalization reaction. The vinylon was somewhat stable, even in a high-hydration environment. First, we prepared a crosslinked SPPSU-vinylon membrane using thermal crosslinking and the vinylonization of a SPPSU-PVA composite, and these methods appeared promising for the thinning of other polymer electrolyte membranes.

\section{Experimental}

\subsection{Materials}

Polyvinyl acetate (PVAc, $\left.\left(\mathrm{C}_{4} \mathrm{H}_{6} \mathrm{O}_{2}\right)_{\mathrm{n}}, \mathrm{Mw}=100,000\right)$ was purchased from Sigma-Aldrich Corporation (St. Louis, MO, USA). A DuPontTM Nafion212 membrane (NR-212) was purchased from DuPont (USA). Methanol $\left(\mathrm{CH}_{3} \mathrm{OH}\right)$, formaldehyde $\left(\mathrm{CH}_{2} \mathrm{O}, 37 \%\right)$, sodium chloride $(\mathrm{NaCl})$, sodium hydroxide $(\mathrm{NaOH})$, and sulfuric acid $\left(\mathrm{H}_{2} \mathrm{SO}_{4}\right)$ were purchased from Nacalai Tesque, Inc. Polyphenylsulfone (Solvay Radel R-5000 NT) (Mn = 26,000; $\mathrm{Mw}=50,000 ; \mathrm{Mw} / \mathrm{Mn}=1.9$ ) was provided by Solvay Specialty Polymers Japan K.K. (glass transition temperature $\left(\mathrm{T}_{\mathrm{g}}\right)=220^{\circ} \mathrm{C}$, (Tokyo, Japan). A dialysis tubing cellulose membrane, which has a molecular weight cut-off (MWCO) of 14,000, and dimethyl sulfoxide (DMSO) were purchased from Sigma-Aldrich Co., Ltd. Deionized (DI) water was obtained using a PURELAB ${ }^{\circledR}$ Option-R 7 ELGA LabWater, at $15 \mathrm{Mohm} \mathrm{cm}$ and $25^{\circ} \mathrm{C}$. Sodium sulfate $\left(\mathrm{Na}_{2} \mathrm{SO}_{4}\right)$ and Iron (II) chloride tetrahydrate $\left(\mathrm{FeCl}_{2} \cdot 4 \mathrm{H}_{2} \mathrm{O}\right)$ were purchased from Fujifilm Wako Pure Chemical Corporation (Osaka, Japan).

\subsection{Synthesis of SPPSU and PVA, and Preparation of CSPPSU-vinylon Membranes}

The synthesis and properties of SPPSU $(\mathrm{Mw} \approx 150,000)$ have been described in detail in previous reports $[3,19]$. PVA was synthesized using the following method. PVAc $(1 \mathrm{~g})$ was dissolved in a flask with methanol $(50 \mathrm{~mL})$. Then, a $40 \% \mathrm{NaOH}$ solution was added, and the mixture was allowed to react at $40{ }^{\circ} \mathrm{C}$ for $10 \mathrm{~min}$ (saponification). The reaction mixture was washed with methanol 4 times and filtered. To remove the remaining solvent, the product was dried at $80^{\circ} \mathrm{C}$ for $24 \mathrm{~h}$, and PVA $(0.5 \mathrm{~g}$, $\mathrm{Mw} \approx 50,000)$ was obtained. Crosslinked SPPSU-vinylon membranes were obtained from SPPSU and PVA using the following method. A glass vial was charged with SPPSU $(0.5 \mathrm{~g})$ and DMSO $(20 \mathrm{~mL})$, and dissolved. PVA $(0.025 \mathrm{~g}, 0.05 \mathrm{~g}, 0.1 \mathrm{~g})$ and DMSO $(4 \mathrm{~mL})$ were put into another glass vial and dissolved. Then, the PVA-DMSO solution was added to the SPPSU-DMSO solution, and the mixture was stirred for $1 \mathrm{~h}$. The SPPSU-PVA-DMSO solution was transferred to a glass container, dried for $24 \mathrm{~h}$ at $80^{\circ} \mathrm{C}$, and then annealed in air at $120^{\circ} \mathrm{C}(24 \mathrm{~h}), 160^{\circ} \mathrm{C}(24 \mathrm{~h})$, and $180^{\circ} \mathrm{C}(24 \mathrm{~h})$. Next, the vinylon from 
the PVA was prepared using a formalization solution $\left(\mathrm{H}_{2} \mathrm{O}: \mathrm{H}_{2} \mathrm{SO}_{4}: \mathrm{Na}_{2} \mathrm{SO}_{4}: \mathrm{CH}_{2} \mathrm{O}=1.00: 0.21: 0.20: 0.06\right.$ in mass ratio) reaction, for $2 \mathrm{~h}$ at $60{ }^{\circ} \mathrm{C}$. Activation was performed using the following procedure: heating in $0.5 \mathrm{M} \mathrm{NaOH}$ at $80{ }^{\circ} \mathrm{C}$ overnight, washing in $\mathrm{DI} \mathrm{H}_{2} \mathrm{O}$, heating at $1 \mathrm{M} \mathrm{H}_{2} \mathrm{SO}_{4}$ at $80^{\circ} \mathrm{C}$ for $2 \mathrm{~h}$, and washing in $\mathrm{DI}_{2} \mathrm{O}$ for $2 \mathrm{~h}$. Finally, the crosslinked SPPSU-vinylon membranes were dried at room temperature before use. The crosslinked SPPSU-vinylon membranes were very flexible and dark brown. The classification of the crosslinked SPPSU-vinylon membranes is shown in Table 1.

Table 1. Classification of crosslinked sulfonated polyphenylsulfone-vinylon (CSPPSU-vinylon) membranes.

\begin{tabular}{ccc}
\hline Varied Parameter & Variable Parameter & Membrane Classification \\
\hline \multirow{3}{*}{ PVA loading $(w \mathrm{t} \%)$} & 0 & CSPPSU \\
\cline { 2 - 3 } & 5 & CSPPSU-5vinylon \\
\cline { 2 - 3 } & 10 & CSPPSU-10vinylon \\
\hline
\end{tabular}

2.3. Iron-Exchange Chromotography (IEC), D.S. (Degree of Sulfonation), Water-Uptake (W.U.), $\lambda$, and Crosslink Rates ( $D_{\text {crosslink }}$ )

The IEC values were determined using the following equation: IEC $(\mathrm{meq} / \mathrm{g})=\mathrm{cv} / \mathrm{W}_{\mathrm{dry}}$, where $\mathrm{c}(\mathrm{mmol} / \mathrm{L})$ is the concentration of standardized $\mathrm{NaOH}$ aq. used for titration $(0.01 \mathrm{~mol} / \mathrm{L}), v(\mathrm{~L})$ is the volume of standardized $\mathrm{NaOH}$ aq. used for titration, and $\mathrm{W}_{\mathrm{dry}}(\mathrm{g})$ is the mass of the dry membrane. The water-uptake (W.U.) of the membranes at room temperature was calculated using the following: W.U. $(\%)=\left[\left(\mathrm{W}_{\text {wet }}-\mathrm{W}_{\mathrm{dry}}\right) / \mathrm{W}_{\mathrm{dry}}\right] \times 100$, where $\mathrm{W}_{\text {wet }}$ is the mass of the wet membrane. The hydration number $(\lambda)$ for the membranes was determined using the following: $\lambda\left(\left[\mathrm{H}_{2} \mathrm{O}\right] /\left[\mathrm{SO}_{3} \mathrm{H}\right]\right)=\left[1000\left(\mathrm{~W}_{\text {wet }}\right.\right.$ $\left.\left.-\mathrm{W}_{\text {dry }}\right)\right] / 18 \mathrm{~W}_{\text {dry }}$ IEC. The degree of crosslinking (crosslink rate, $\mathrm{D}_{\text {crosslink }}$ ) in the membranes was determined using the following: $\mathrm{D}_{\text {crosslink }}(\%)=\left[\left(\mathrm{IEC}_{\text {before annealing }}-\mathrm{IEC}_{\mathrm{after}}\right.\right.$ annealing $) /\left[E \mathrm{I}_{\text {before annealing }}\right]$ $\times 100$ [19].

\subsection{Oxidative Stability (Fenton's Test)}

The oxidative stabilities of the membranes were evaluated by immersing a small piece of the membrane into Fenton's reagent $\left[3 \mathrm{wt} \% \mathrm{H}_{2} \mathrm{O}_{2}\right.$ and $2 \mathrm{ppm} \mathrm{Fe}(\mathrm{II})$ (added as $\mathrm{FeCl}_{2} \cdot 4 \mathrm{H}_{2} \mathrm{O}$ )], at $\sim 80{ }^{\circ} \mathrm{C}$ for $1 \mathrm{~h}$ while stirring. The samples were dried at $80^{\circ} \mathrm{C}$ before the measurements. The membranes were repeatedly washed with $\mathrm{DI} \mathrm{H}_{2} \mathrm{O}$, and dried at $80^{\circ} \mathrm{C}$ overnight following the reaction. The oxidative stabilities were determined as follows: [(mass of residual membrane after the test)/(initial mass of membrane) $] \times 100$.

\subsection{Chemical Structure of the Samples}

Fourier-transform infrared (FTIR) absorption spectra of the samples were obtained on a Thermo Scientific Nicolet 6700 spectrometer, in an attenuated total reflection (ATR) mode.

\subsection{Mechanical and Thermal Behavior of the Samples}

Stress-strain tests on the membranes were accomplished using a Tension Test Machine (Shimazu, EZ-S) at room temperature [19]. The thermal and mass properties of the membranes were investigated using thermogravimetric and mass analyses with a Thermoplus TG8120 TG-DTA/H (Rigaku Co. Ltd., Japan). The samples were heated from 60 to $800{ }^{\circ} \mathrm{C}$ at $5{ }^{\circ} \mathrm{C} / \mathrm{min}$ in air, after keeping them for $1 \mathrm{~h}$ at $60^{\circ} \mathrm{C}$. 


\subsection{Conductivity and Single Cell Measurements of the Samples}

The proton conductivities of the membranes were evaluated using a four-point probe impedance spectroscopy. For the membrane electrode assembly (MEA), the thickness of the membranes was approximately $50 \mu \mathrm{m}$, and a Pt/C/ionomer (ionomer/carbon =1) catalyst electrode (EIWA corporation) containing $0.3 \mathrm{mg} / \mathrm{cm}^{2}$ of Pt on a GDL electrode (Sigracet ${ }^{\circledR}$ GDL 25BC of SGL Group Co. Ltd., Japan), was used. The effective electrode area of the single cell was $4 \mathrm{~cm}^{2}$. The MEA was acquired by loading a membrane between the anode and cathode, and hot-pressing at $130{ }^{\circ} \mathrm{C}$ and $\sim 9.8 \mathrm{kN}$ for $20 \mathrm{~min}$. A single cell performance was measured in relation to the amount of hydrogen $\left(\mathrm{H}_{2}\right)$ and oxygen $\left(\mathrm{O}_{2}\right)$ at the anode and cathode, respectively, at $80{ }^{\circ} \mathrm{C}, 100 \%$ and $60 \% \mathrm{RH}$ (relative humidity), and ambient pressure. The gas flow rate of hydrogen and oxygen were $50 \mathrm{cc} / \mathrm{min}$ and $100 \mathrm{cc} / \mathrm{min}$, respectively. Linear sweep voltammetry (LSV) was evaluated in the potential range of $0.02-0.5 \mathrm{~V}$ at $2 \mathrm{mV} / \mathrm{s}$ [19].

\section{Results and Discussion}

\subsection{CSPPSU-vinylon Membranes}

Thermally crosslinked membranes of SPPSU polymers have been reported in previous research $[5,19]$. Crosslinking occurs between the sulfone groups of SPPSU under a thermal environment. The same phenomenon occurs in composite membranes of SPPSU polymers and PVA polymers. In addition, crosslinking occurs between the sulfone groups of SPPSU and the hydroxy groups of PVA upon heat treatment. A crosslinked SPPSU-vinylon membrane could be obtained using a formalization reaction with PVA (Figure 1).

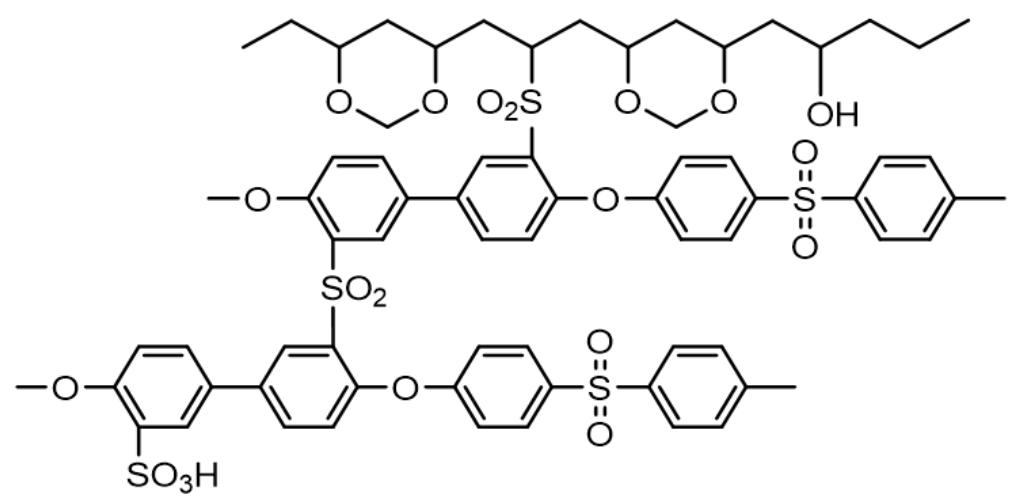

Figure 1. Schematic diagram of CSPPSU-vinylon membrane.

PVA was synthesized by hydrolyzing PVAc (saponification). The peak for the carbonyl groups $(\mathrm{C}=\mathrm{O})$ of the PVAc appeared at $1728 \mathrm{~cm}^{-1}$ in the IR spectrum (Figure 2a). For PVA synthesized using the hydrolysis of PVAc, the peak due to the carbonyl group disappeared, and new peaks for the $\mathrm{OH}$ groups appeared at $3272 \mathrm{~cm}^{-1}, 1655 \mathrm{~cm}^{-1}$, and $1324 \mathrm{~cm}^{-1}$ (Figure $2 \mathrm{~b}$ ). These results indicate that PVA can be obtained by hydrolyzing PVAc. The IR spectra of the CSPPSU-vinylon membranes did not change significantly with the amount of PVA added and had similar characteristics (Figure 2c-e). The peaks for both SPPSU and PVA appeared in the spectra. The crosslinking of SPPSU has been reported in more detail in a previous paper [3,5]. In the IR spectra, it was not clear whether the sulfone bridge of SPPSU and the hydroxy group of PVA were crosslinked using hydrolysis to form a sulfone bridge (- $\left.\mathrm{SO}_{2}-\right)$. Moreover, it was difficult to determine whether PVA had been changed to vinylon. However, we can assume that crosslinking and vinylon formation progressed, as the appearance of the obtained membranes were very uniform and flexible. Figure 2 and Table 2 show the FTIR spectra and summarize the assignments of the peaks, respectively. 


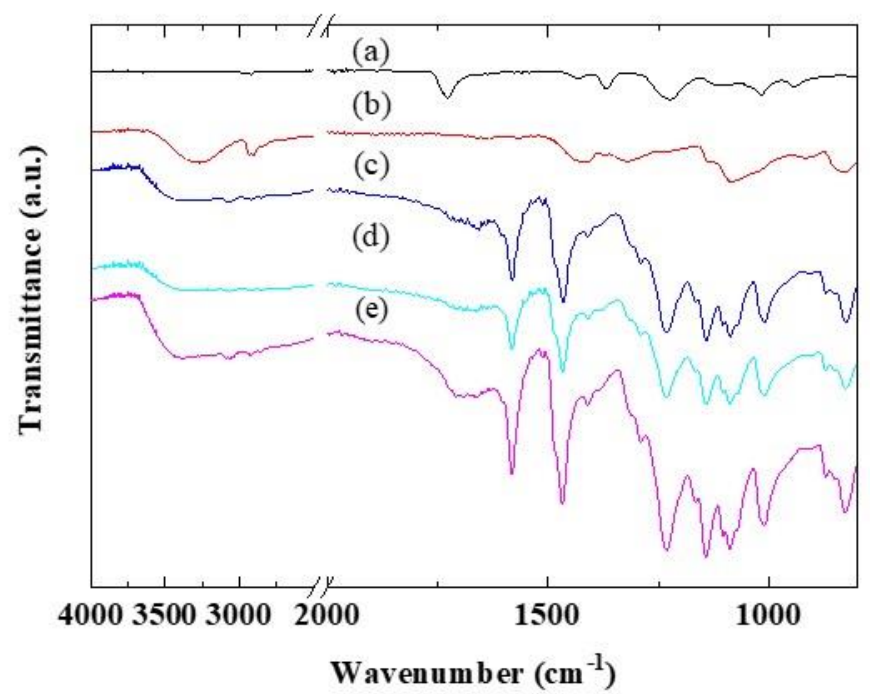

Figure 2. Fourier transform infrared (FTIR) properties of (a) polyvinyl acetate (PVAc), (b) syn. polyvinyl alcohol (PVA), (c) CSPPSU-5vinylon, (d) CSPPSU-10vinylon, and (e) CSPPSU-20vinylon membranes with different amounts of PVA.

Table 2. Summary of assignments of the FTIR spectra of PVAc, syn. PVA, and CSPPSU-vinylon membranes.

\begin{tabular}{cccc}
\hline Polymer & PVAc & PVA & CSPPSU-vinylon \\
\hline$v \mathrm{H}-\mathrm{O}-\mathrm{H}\left(\mathrm{cm}^{-1}\right)$ & & 3272 & 3421 \\
\hline $\begin{array}{c}\text { Aromatic } \\
v \mathrm{C}-\mathrm{H}\left(\mathrm{cm}^{-1}\right)\end{array}$ & & $3093,3074,3038$ \\
\hline $\begin{array}{c}\text { Aliphatic } \\
\text { C-H }\left(\mathrm{cm}^{-1}\right)\end{array}$ & $\begin{array}{c}\text { 2974, 2928, 2852, 1431, } \\
1367\end{array}$ & $2932,2898,1424$ & 2920,2846 \\
\hline$\delta \mathrm{s}, \mathrm{H}-\mathrm{O}-\mathrm{H}\left(\mathrm{cm}^{-1}\right)$ & & 1655 & 1714,1665 \\
\hline $\begin{array}{c}\text { Aromatic } \\
v \mathrm{C}=\mathrm{C}\left(\mathrm{cm}^{-1}\right)\end{array}$ & & 1584,1469 \\
\hline$v \mathrm{C}=\mathrm{O}\left(\mathrm{cm}^{-1}\right)$ & 1728 & 1324 \\
\hline$\delta \mathrm{s}, \mathrm{C}-\mathrm{O}-\mathrm{H}\left(\mathrm{cm}^{-1}\right)$ & & 1324 & 1232 \\
\hline$v a s, \mathrm{C}-\mathrm{O}-\mathrm{C}\left(\mathrm{cm}^{-1}\right)$ & & 1568,1083 & \\
\hline $\begin{array}{c}\text { Aliphatic } \\
v \mathrm{C}-\mathrm{O}\left(\mathrm{cm}^{-1}\right)\end{array}$ & $1220,1116,1016,939$ & 1142 \\
\hline$v \mathrm{~s}, \mathrm{O}=\mathrm{S}=\mathrm{O}\left(\mathrm{cm}^{-1}\right)$ & & & \\
\hline
\end{tabular}

\subsection{Thermal and Mechanical Properties of the CSPPSU-vinylon Membranes}

The thermal (Figure 3) and mechanical properties (Figure 4) of the CSPPSU-vinylon membranes, prepared by varying the amount of PVA added, were investigated. The CSPPSU-vinylon membrane exhibited a lower desorption of the sulfone groups and had a lower decomposition temperature of the polymer backbone than the CSPPSU membrane (Figure 3, Table 3). The thermal behavior of the CSPPSU-vinylon membrane on the amount of PVA added was similar. As for the weight reduction ratio of water due to water vaporization, the CSPPSU-vinylon membrane had a higher water content than the CSPPSU membrane (Table 3). In the TGA (thermal gravimetric analysis) curves for the CSPPSU sample, residuals (inorganic substances) appeared after $600{ }^{\circ} \mathrm{C}$. However, every CSPPSU-vinylon sample burned at $600^{\circ} \mathrm{C}$. This suggests that the SPPSU and the vinylon were crosslinked into one polymer. 

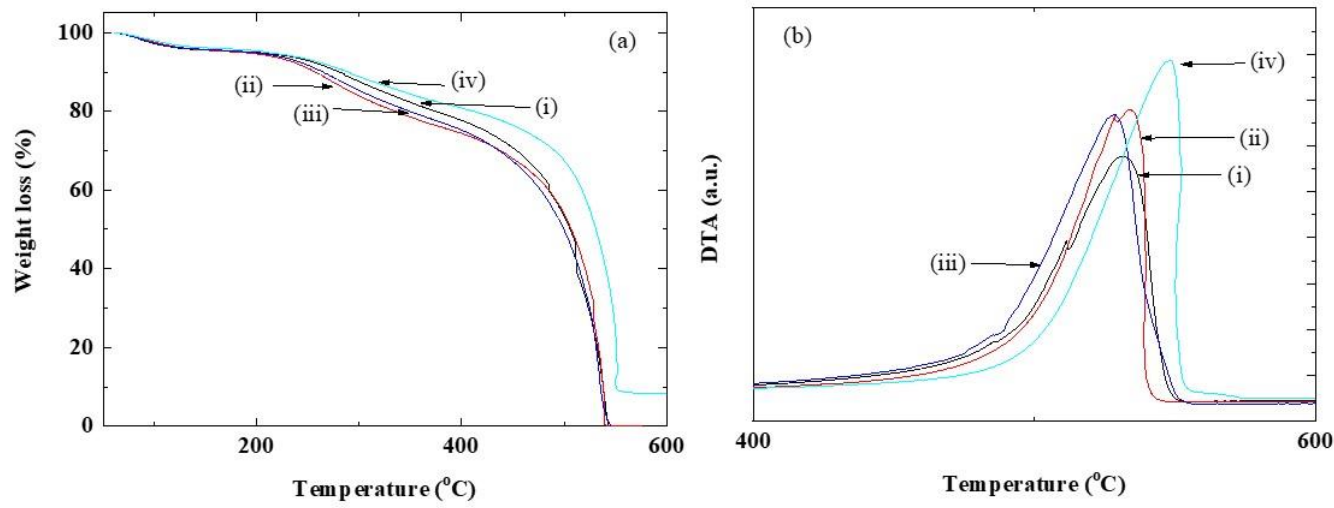

Figure 3. (a) TG (thermal gravimetric) and (b) DTA (differential thermal analysis) results of (i) CSPPSU-5vinylon, (ii) CSPPSU-10vinylon, (iii) CSPPSU-20vinylon, and (iv) CSPPSU membranes.

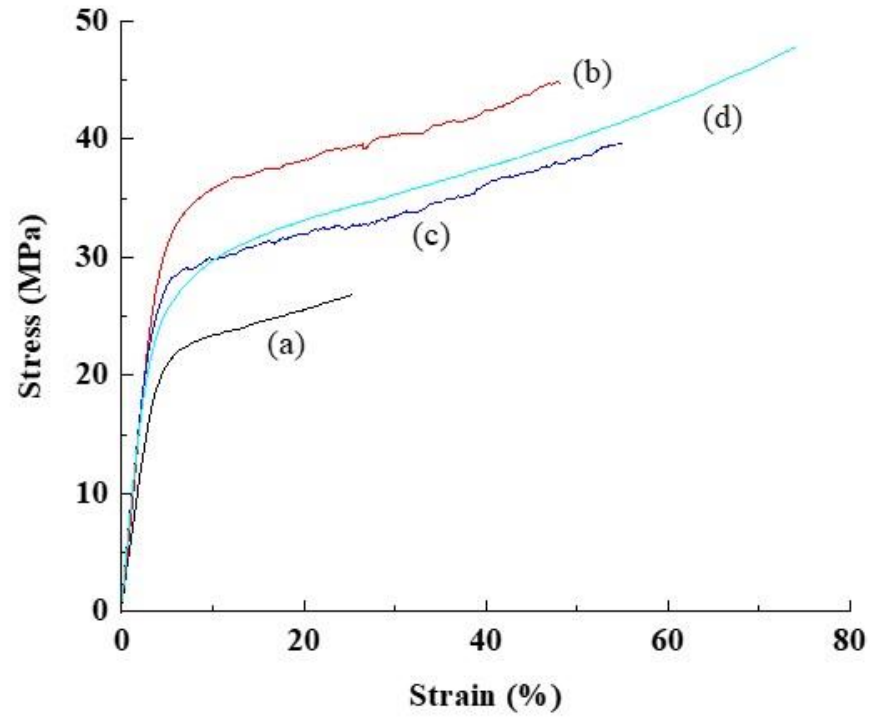

Figure 4. Stress-strain properties of (a) CSPPSU-5vinylon, (b) CSPPSU-10vinylon, (c) CSPPSU-20vinylon, and (d) CSPPSU membranes.

Table 3. Summary of temperature ranges and mass losses observed for each step in the TG-DTA curves for CSPPSU-vinylon membranes.

\begin{tabular}{|c|c|c|c|c|c|}
\hline \multirow[t]{2}{*}{$\begin{array}{l}\text { Sample } \\
\text { Name }\end{array}$} & \multicolumn{2}{|c|}{$\begin{array}{c}\text { Evaporation of } \mathrm{H}_{2} \mathrm{O} \\
\text { Interacting with }-\mathrm{SO}_{3} \mathrm{H} \\
\text { or }-\mathrm{OH} \text { Group }\end{array}$} & \multicolumn{2}{|c|}{$\begin{array}{c}\text { Desubstitution of }-\mathrm{SO}_{3} \mathrm{H} \\
\text { Group }\end{array}$} & \multirow{2}{*}{$\begin{array}{c}\text { Thermal } \\
\begin{array}{c}\text { Decomposition of } \\
\text { Polymer Backbone }\end{array} \\
\text { Peak of Exothermic }\left({ }^{\circ} \mathrm{C}\right)\end{array}$} \\
\hline & $\Delta \mathrm{T}\left({ }^{\circ} \mathrm{C}\right)$ & $\begin{array}{l}\Delta \mathrm{Wt} . \text { Loss } \\
\quad(\%)\end{array}$ & $\Delta \mathrm{T}\left({ }^{\circ} \mathrm{C}\right)$ & $\begin{array}{l}\Delta \mathrm{Wt} . \text { Loss } \\
\quad(\%)\end{array}$ & \\
\hline CSPPSU & $61-210$ & 4.5 & $210-453$ & 19.1 & 548 \\
\hline $\begin{array}{l}\text { CSPPSU- } \\
\text { 5vinylon }\end{array}$ & $61-212$ & 4.9 & $212-403$ & 17.5 & 532 \\
\hline $\begin{array}{l}\text { CSPPSU- } \\
\text { 10vinylon }\end{array}$ & 61-197 & 5.0 & $197-389$ & 19.5 & 534 \\
\hline $\begin{array}{l}\text { CSPPSU- } \\
\text { 20vinylon }\end{array}$ & 61-197 & 5.0 & $197-400$ & 19.8 & 528 \\
\hline
\end{tabular}

On the other hand, the dependence of the CSPPSU-vinylon membrane on the amount of added PVA, was noticeable in the evaluation of its mechanical properties (Figure 4, Table 4). The CSPPSU-10vinylon membranes obtained by adding $10 \mathrm{wt} \%$ PVA to SPPSU had higher tensile strengths than the other 
crosslinked membranes. However, the tensile elongation increased with an increase in the amount of added PVA, and the tensile strength and tensile elongation of the CSPPSU-5vinylon membrane containing $5 \mathrm{wt} \%$ PVA, was low in comparison to the other membranes. The flexural modulus of the membrane decreased with an increase in the amount of PVA. The tensile elongation characteristics of the CSPPSU-vinylon membrane were smaller than those of the CSPPSU membranes. The favorable tensile elongation of the CSPPSU-10vinylon membrane may be due to its better homogeneity in comparison to the other membranes.

Table 4. Mechanical properties of CSPPSU-vinylon membranes.

\begin{tabular}{|c|c|c|c|c|}
\hline & CSPPSU & $\begin{array}{l}\text { CSPPSU } \\
-5 \text { vinylon }\end{array}$ & $\begin{array}{c}\text { CSPPSU } \\
\text {-10vinylon }\end{array}$ & $\begin{array}{c}\text { CSPPSU } \\
\text {-20vinylon }\end{array}$ \\
\hline Tensile strength (MPa) & 48 & 27 & 45 & 40 \\
\hline Tensile elongation (\%) (break) & 74 & 26 & 48 & 55 \\
\hline Flexural modulus $(\mathrm{MPa}) *$ & 757 & 781 & 759 & 548 \\
\hline
\end{tabular}

\subsection{Proton Conductivities of the CSPPSU-vinylon Membranes}

Polymer electrolyte membranes for high-performance fuel cells require high proton conductivities of $>0.01 \mathrm{~S} / \mathrm{cm}$, from low to high temperatures and high to low humidification [1]. The conductivity of the CSPPSU-vinylon membranes due to the difference in the amount of PVA added-which is the average value of the error bars of the data obtained after three measurements with varying humidity, at cell temperatures of 40 and $120^{\circ} \mathrm{C}$-is shown in Figure 5. Table 5 shows the physicochemical properties of the CSPPSU-vinylon membranes, depending on the amount of PVA added. The IEC value of the SPPSU polymer was $3.8 \mathrm{meq} / \mathrm{g}$, and the IEC value of the SPPSU-PVA composite polymer was assumed to be equivalent to the IEC value of the SPPSU polymer. Then, the crosslinking degree $\left(\mathrm{D}_{\text {crosslink }}\right)$ of the CSPPSU-vinylon membranes was calculated. Moreover, the chemical stability of the membrane was determined using Fenton's reagent $\left(3 \mathrm{wt} \% \mathrm{H}_{2} \mathrm{O}_{2}+2 \mathrm{ppm} \mathrm{Fe}(\mathrm{II}), 80{ }^{\circ} \mathrm{C}, 1 \mathrm{~h}\right.$ ). Since vinylon has a high chemical resistance, we thought that the chemical stability of CSPPSU [19] would be improved by incorporating vinylon. However, as shown in Table 5, there was little improvement. With Fenton's reagent, the CSPPSU membrane was radically attacked from the edge, but the CSPPSU-10vinylon membrane was attacked from the inside of the membrane, generating a hole. It is thought that the SPPSU part is selectively vulnerable to attack.
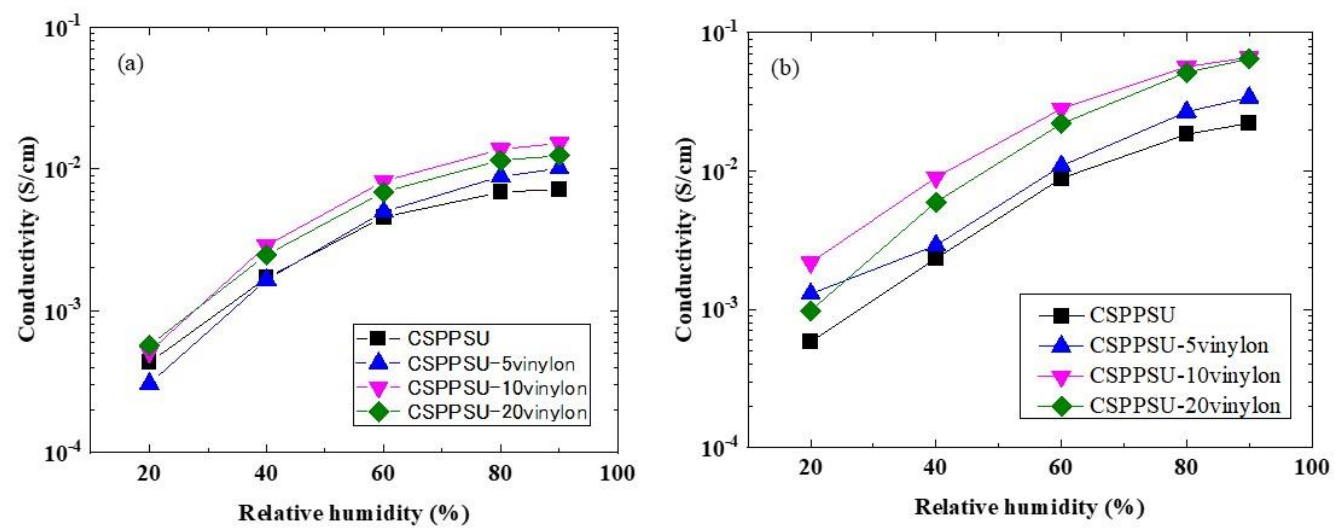

Figure 5. Proton conductivities of the CSPPSU-vinylon membranes vs. the relative humidity at (a) 40 and $(\mathbf{b}) 120^{\circ} \mathrm{C}$. 
Table 5. Physicochemical and conductivity properties of the CSPPSU-vinylon membranes.

\begin{tabular}{|c|c|c|c|c|c|c|}
\hline \multicolumn{3}{|c|}{ Sample Name } & CSPPSU & $\begin{array}{l}\text { CSPPSU } \\
-5 \text { vinylon }\end{array}$ & $\begin{array}{c}\text { CSPPSU } \\
\text {-10vinylon }\end{array}$ & $\begin{array}{l}\text { CSPPSU } \\
\text {-20vinylon }\end{array}$ \\
\hline \multicolumn{3}{|c|}{ IEC (meq/g) } & 2 & 2.2 & 2.1 & 2.1 \\
\hline \multicolumn{3}{|c|}{ W.U. (\%) } & 43 & 38 & 66 & 36 \\
\hline \multicolumn{3}{|c|}{$\lambda$} & 11.9 & 9.6 & 17.5 & 9.5 \\
\hline \multicolumn{3}{|c|}{$\mathrm{D}_{\text {crosslink }}(\%)$} & 47.3 & 42.1 & 44.7 & 44.7 \\
\hline \multicolumn{3}{|c|}{$\mathrm{R}_{\text {oxidation }}(\%)$} & 91-99 & $\mathrm{a}^{\mathrm{a}}$ & $81-99$ & ${ }^{\mathrm{a}}$ \\
\hline \multirow{6}{*}{$\begin{array}{l}\text { Conductivity } \\
(\mathrm{mS} / \mathrm{cm})\end{array}$} & \multirow{2}{*}{$40^{\circ} \mathrm{C}$} & $20 \% \mathrm{RH}$ & 0.43 & 0.31 & 0.52 & 0.57 \\
\hline & & $90 \% \mathrm{RH}$ & 7.23 & 10.12 & 15.23 & 12.43 \\
\hline & \multirow{2}{*}{$80^{\circ} \mathrm{C}$} & $20 \% \mathrm{RH}$ & 0.7 & 0.7 & 0.9 & 1.1 \\
\hline & & $90 \% \mathrm{RH}$ & 18 & 36 & 56 & 55 \\
\hline & \multirow{2}{*}{$120^{\circ} \mathrm{C}$} & $20 \% \mathrm{RH}$ & 0.6 & 1.3 & 2.2 & 1.0 \\
\hline & & $90 \% \mathrm{RH}$ & 22 & 34 & 66 & 65 \\
\hline
\end{tabular}

On the other hand, the conductivity of the CSPPSU-vinylon electrolyte membrane increased with increases in the temperature and humidity. The conductivity of the CSPPSU-vinylon membrane was higher than that of the CSPPSU membrane. In particular, the CSPPSU-10vinylon membrane had a higher conductivity than the other membranes. The diffusion of protons in the electrolyte membrane depended on the concentration and proton mobility of the sulfonic acid groups $\left(-\mathrm{SO}_{3} \mathrm{H}\right)$ in the electrolyte membrane, and became faster as the temperature and humidity were increased. In addition, the nanostructure (conduction path) of the electrolyte membrane was greatly affected. The homogeneity of the CSPPSU-10vinylon membrane was better than that of the other membranes (Figure 4). As shown in Table 5, changes in the IEC values of the CSPPSU-vinylon membrane due to the difference in the amount of PVA added, was small and slightly higher than those of the CSPPSU membrane. However, the water content and the number of water molecules per sulfonic acid group $(\lambda)$ of the CSPPSU-10vinylon membrane, were higher than those of the other crosslinked membranes. These differences contributed to the high proton conductivity of the CSPPSU-10vinylon membrane. The degree of crosslinking of the CSPPSU-vinylon membrane was $42 \%-45 \%$. It is possible that the hydroxy groups $(-\mathrm{OH})$ of vinylon in the CSPPSU-vinylon membrane contributed to the proton transfer. From the above, it is clear that the conduction mechanism of the SPPSU-vinylon composite membrane is very complicated.

\subsection{Fuel Cell Properties using CSPPSU-vinylon Membranes}

The performance of fuel cells depends not only on the ionic conductivity of the electrolyte membrane, but also on the interfaces between the electrode layers (catalyst, carbon, ionomer) and between the membrane and the electrode layer [45,49]. Here, the electrode layer and the MEA (membrane electrode assembly) were placed under the same conditions, and only the electrolyte membrane was different. In addition, the measurement conditions for obtaining the current-voltage (I-V) characteristics were the same. The I-V characteristics were evaluated at a cell temperature of $80{ }^{\circ} \mathrm{C}$, and humidities of $100 \% \mathrm{RH}$ and $60 \% \mathrm{RH}$. Figure 6 shows $\mathrm{I}-\mathrm{V}_{\text {ir }}$ free and I-iR loss characteristics, evaluated using CSPPSU-10vinylon, CSPPSU, and Nafion212 membranes. The resistance of the single cell using the CSPPSU-10vinylon membrane was higher than that of the Nafion212 membrane, and lower than that of the CSPPSU membrane (Table 6). This tendency in the level of conductivity is the same as that using only the electrolyte membrane (Figure 5). Moreover, the $\mathrm{I}-\mathrm{V}_{\mathrm{iR}}$ free characteristics showed the same tendency as the resistance characteristics of the unit cell. On the other hand, when using the CSPPSU-10vinylon membrane, a current of $1.5 \mathrm{~A} / \mathrm{cm}^{2}$ or more was obtained. In the case of 
Nafion212 and the CSPPSU membranes, the current was less than $1.5 \mathrm{~A} / \mathrm{cm}^{2}$ at $100 \% \mathrm{RH}$, and less than $1 \mathrm{~A} / \mathrm{cm}^{2}$ at $60 \% \mathrm{RH}$. Under high humidification conditions, when a high current was applied, flooding occurred on the cathode side, and the voltage tended to drop sharply. Moreover, under low humidification conditions, the membrane resistance increased due to the drying of the membrane, making it difficult to obtain a high current. However, when the CSPPSU-10vinylon membrane was used, a high current without a sharp drop in voltage was obtained, under both high and low humidity conditions. The CSPPSU-vinylon membrane, therefore, seems to have an excellent water treatment ability. These results suggest that the CSPPSU-vinylon membrane would be suitable for thin membrane applications.
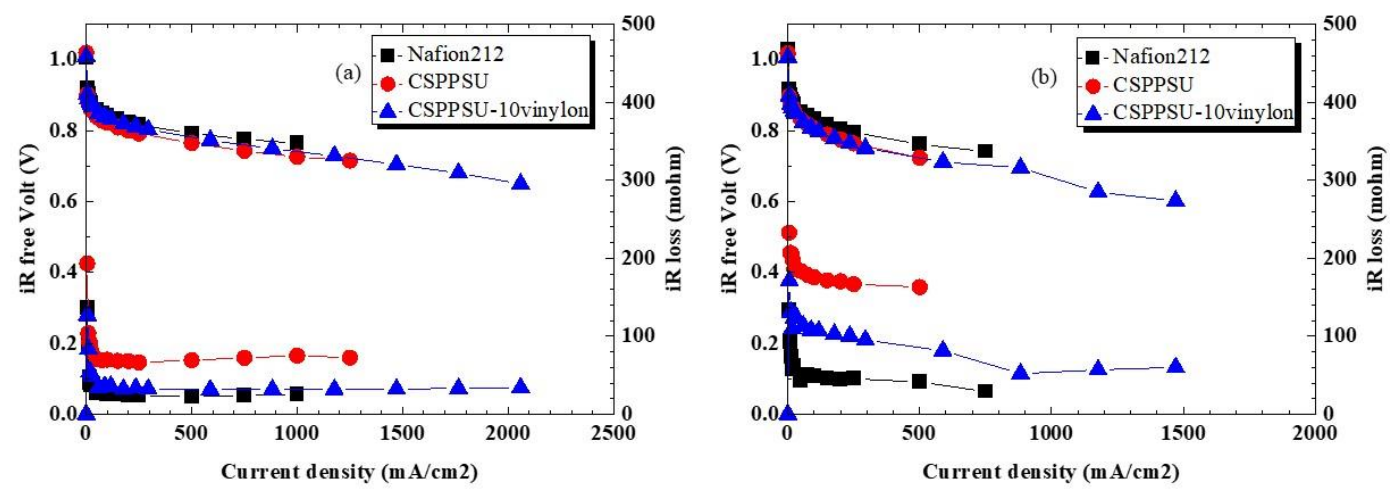

Figure 6. Current-voltage (I-V) properties of CSPPSU-10vinylon, CSPPSU, and Nafion212 membranes: (a) $\mathrm{I}-\mathrm{V}_{\mathrm{iR}}$ free at $80{ }^{\circ} \mathrm{C}, 100 \% \mathrm{RH}$ and (b) $\mathrm{I}-\mathrm{V}_{\text {iR }}$ free at $80{ }^{\circ} \mathrm{C}, 60 \% \mathrm{RH}$.

Table 6. I-V and $\mathrm{H}_{2}$ crossover data for single cells using the CSPPSU-10vinylon, CSPPSU, and Nafion212 membranes.

\begin{tabular}{|c|c|c|c|c|c|}
\hline & \multicolumn{3}{|c|}{$80^{\circ} \mathrm{C}, 100 \% \mathrm{RH}$} & \multicolumn{2}{|c|}{$80{ }^{\circ} \mathrm{C}, 60 \% \mathrm{RH}$} \\
\hline & $\begin{array}{c}\text { OCV } \\
\text { (V) }\end{array}$ & $\begin{array}{c}\text { iR Loss } \\
(\mathrm{mohm}) \\
\text { @ } 1 \mathrm{~A} / \mathrm{cm}^{2}\end{array}$ & $\begin{array}{c}\mathrm{H}_{2} \text { Crossover } \\
\left(\mathrm{mA} / \mathrm{cm}^{2}\right) \\
\text { @ } 0.4 \mathrm{~V}\end{array}$ & $\begin{array}{c}\text { OCV } \\
(\mathrm{V})\end{array}$ & $\begin{array}{c}\text { iR Loss } \\
\text { (mohm) } \\
@ 1 \mathrm{~A} / \mathrm{cm}^{2}\end{array}$ \\
\hline CSPPSU & 1.020 & 73 & 0.085 & 1.018 & 161 \\
\hline CSPPSU-10vinylon & 1.010 & 69 & 0.245 & 1.008 & 119 \\
\hline Nafion212 & 1.005 & 24 & 1.24 & 1.029 & 42 \\
\hline
\end{tabular}

Figure 7 shows the hydrogen crossover characteristics of the CSPPSU-10vinylon, CSPPSU, and Nafion212 membranes. The crossover properties of the CSPPSU-10vinylon membrane are five times lower than those of the Nafion212 membrane, and three times higher than those of the CSPPSU membrane (Table 6). We can assume that the crosslinking of SPPSU with vinylon increases the conduction paths (volume fraction) in the nanophase, and hydrogen crossover is higher than that of the CSPPSU membrane. 


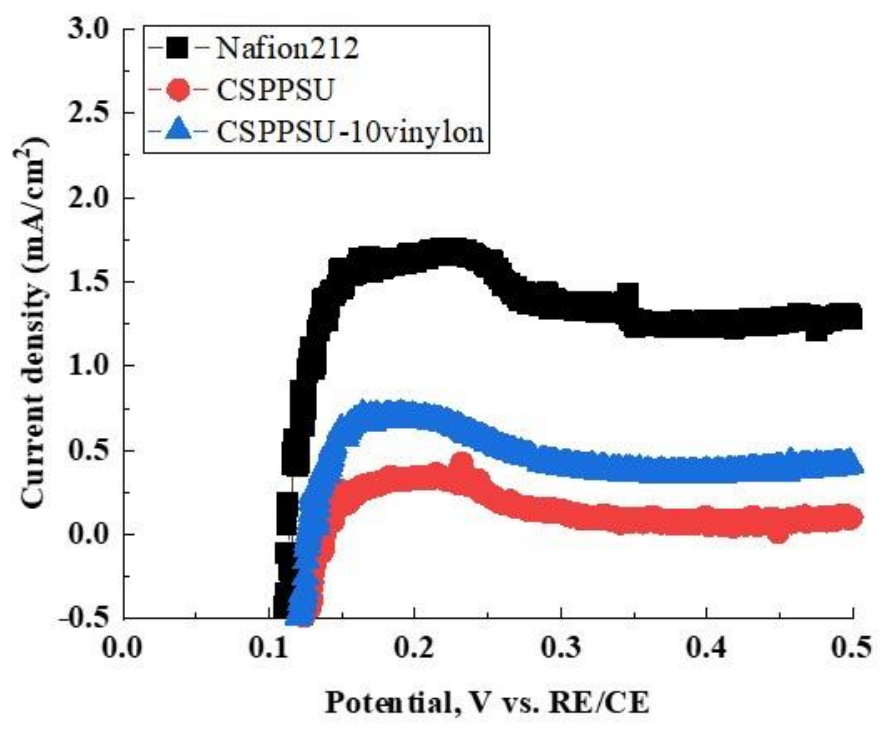

Figure 7. Hydrogen crossover properties of CSPPSU-10vinylon, CSPPSU, and Nafion212 membranes at $80{ }^{\circ} \mathrm{C}$ and $100 \% \mathrm{RH}$.

\section{Conclusions}

We focused on improving the performance of CSPPSU membranes with hydrocarbon-based SPPSU polymers, as an alternative electrolyte to fluoropolymer electrolytes. To improve the conductivity and I-V performance properties of CSPPSU membranes, SPPSU and PVA were crosslinked, and CSPPSU-vinylon membranes were synthesized by the formalization of PVA, and compared with Nafion212 and CSPPSU membranes. The conductivities of the CSPPSU-vinylon membranes were higher than those of the CSPPSU membrane. From the results of the fuel cell evaluation, higher current densities than those of Nafion212 and CSPPSU membranes were obtained under both high and low humidification conditions. This is due to the effects of vinylon, and it is thought that the CSPPSU-vinylon membrane has excellent water retention under low humidification conditions. Furthermore, the hydrogen gas crossover properties are lower than those of Nafion212. In other words, the CSPPSU-vinylon membrane would be useful for thin membrane applications.

Author Contributions: Conceptualization, J.-D.K.; Data curation, J.-D.K., S.M. and K.T.; Formal analysis, J.-D.K.; Writing—original draft, J.-D.K.; Writing—review \& editing, J.-D.K. All authors have read and agreed to the published version of the manuscript.

Funding: This research received no external funding.

Acknowledgments: This work was partially supported by the MEXT Program for the Development of Environmental Technology, using Nanotechnology from Ministry of Education, Culture, Sports, Science and Technology, Japan.

Conflicts of Interest: The authors declare no conflict of interest.

\section{References}

1. Mauritz, K.A.; Moore, R.B. State of Understanding of Nafion. Chem. Rev. 2004, 104, 4535-4585. [CrossRef]

2. Yandrasits, M.; Lindell, M.; Schaberg, M.; Kurkowski, M. Increasing Fuel Cell Efficiency by Using Ultra-Low Equivalent Weight Ionomers. Electrochem. Soc. Interface 2017, 26, 49-53. [CrossRef]

3. Matsushita, S.; Kim, J.-D. Organic solvent-free preparation of electrolyte membranes with high proton conductivity using aromatic hydrocarbon polymers and small cross-linker molecules. Solid State Ionics 2018, 316, 102-109. [CrossRef]

4. Tashvigh, A.A.; Luo, L.; Chung, T.-S.; Weber, M.; Maletzko, C. A novel ionically cross-linked sulfonated polyphenylsulfone (sPPSU) membrane for organic solvent nanofiltration (OSN). J. Membr. Sci. 2018, 545, 221-228. [CrossRef] 
5. Zhang, Y.; Kim, J.-D.; Miyatake, K. Effect of thermal crosslinking on the properties of sulfonated poly(phenylene sulfone)s as proton conductive membranes. J. Appl. Polym. Sci. 2016, 133, 1-8. [CrossRef]

6. Kim, J.-D.; Ghil, L.-J. Annealing effect of highly sulfonated polyphenylsulfone polymer. Int. J. Hydrog. Energy 2016, 41, 11794-11800. [CrossRef]

7. Lee, H.; Han, M.; Choi, Y.-W.; Bae, B. Hydrocarbon-based polymer electrolyte cerium composite membranes for improved proton exchange membrane fuel cell durability. J. Power Sources 2015, 295, 221-227. [CrossRef]

8. Takamuku, S.; Wohlfarth, A.; Manhart, A.; Räder, P.; Jannasch, P. Hypersulfonated polyelectrolytes: Preparation, stability and conductivity. Polym. Chem. 2015, 6, 1267-1274. [CrossRef]

9. Krishnan, N.N.; Henkensmeier, D.; Jang, J.H.; Hink, S.; Kim, H.-J.; Nam, S.W.; Lim, T.-H. Locally confined membrane modification of sulfonated membranes for fuel cell application. J. Membr. Sci. 2014, 454, 174-183. [CrossRef]

10. Yu, D.M.; Yoon, S.; Kim, T.H.; Lee, J.Y.; Lee, J.; Hong, Y.T. Properties of sulfonated poly(arylene ether sulfone)/electrospun nonwonen polyacrylonitrile composite membrane for proton exchange membrane fuel cells. J. Membr. Sci. 2013, 446, 212-219. [CrossRef]

11. Takamuku, S.; Jannasch, P. Properties and degradation of hydrocarbon fuel cell membranes: A comparative study of sulfonated poly(arylene ether sulfone)s with different positions of the acid groups. Polym. Chem. 2012, 3, 1202-1214. [CrossRef]

12. Wen, P.; Zhong, Z.; Li, L.; Zhang, A.; Li, X.; Lee, M.-H. Photocrosslinking of sulfonated poly(arylene ether sulfone) in a swollen state. J. Mater. Chem. 2012, 22, 22242-22249. [CrossRef]

13. Chen, S.; Zhang, X.; Chen, K.; Endo, N.; Higa, M.; Okamoto, K.-I.; Wang, L. Cross-linked miscible blend membranes of sulfonated poly(arylene ether sulfone) and sulfonated polyimide for polymer electrolyte fuel cell applications. J. Power Sources 2011, 196, 9946-9954. [CrossRef]

14. Feng, S.; Shang, Y.; Xie, X.; Wang, Y.; Xu, J. Synthesis and characterization of crosslinked sulfonated poly(arylene ether sulfone) membranes for DMFC applications. J. Membr. Sci. 2009, 335, 13-20. [CrossRef]

15. Di Vona, M.L.; Luchetti, L.; Spera, G.P.; Sgreccia, E.; Knauth, P. Synthetic strategies for the preparation of proton-conducting hybrid polymers based on PEEK and PPSU for PEM fuel cells. Comptes Rendus Chim. 2008, 11, 1074-1081. [CrossRef]

16. Xing, D.; Kerres, J.A. Improved performance of sulfonated polyarylene ethers for proton exchange membrane fuel cells. Polym. Adv. Technol. 2006, 17, 591-597. [CrossRef]

17. Karlsson, L.E.; Jannasch, P. Polysulfone ionomers for proton-conducting fuel cell membranes. Electrochim. Acta 2005, 50, 1939-1946. [CrossRef]

18. Dyck, A.; Fritsch, D.; Nunes, S.P. Proton-conductive membranes of sulfonated polyphenylsulfone. J. Appl. Polym. Sci. 2002, 86, 2820-2827. [CrossRef]

19. Kim, J.-D.; Ohira, A.; Nakao, H. Chemically Crosslinked Sulfonated Polyphenylsulfone (CSPPSU) Membranes for PEM Fuel Cells. Membranes 2020, 10, 31. [CrossRef]

20. Nor, N.A.M.; Nakao, H.; Othman, M.H.D.; Kim, J.-D. Crosslinked carbon nanodots with highly sulfonated polyphenylsulfone as proton exchange membrane for fuel cell applications. Int. J. Hydrog. Energy 2020, 45, 9979-9988. [CrossRef]

21. Di Vona, M.L.; Alberti, G.; Sgreccia, E.; Casciola, M.; Knauth, P. High performance sulfonated aromatic ionomers by solvothermal macromolecular synthesis. Int. J. Hydrog. Energy 2012, 37, 8672-8680. [CrossRef]

22. Chen, J.; Zhai, M.; Asano, M.; Huang, L.; Maekawa, Y. Long-term performance of polyetheretherketone-based polymer electrolyte membrane in fuel cells at $95^{\circ} \mathrm{C}$. J. Mater. Sci. 2009, 44, 3674-3681. [CrossRef]

23. Goto, K.; Rozhanskii, I.; Yamakawa, Y.; Ohtsuki, T.; Naito, Y. Development of aromatic polymer electrolyte membrane with high conductivity and durability for fuel cell. JSR Tech. Rev. 2009, 116, 1-11. [CrossRef]

24. Di Vona, M.L.; Sgreccia, E.; Licoccia, S.; Alberti, G.; Tortet, L.; Knauth, P. Analysis of temperature-promoted and solvent-assisted cross-linking in sulfonated poly (ether ether ketone)(SPEEK) proton-conducting membranes. J. Phys. Chem. B 2009, 113, 7505-7512. [CrossRef]

25. Vona, M.L.D.; Sgreccia, E.; Licoccia, S.; Khadhraoui, M.; Denoyel, R.; Knauth, P. Composite proton-conducting hybrid polymers: Water sorption isotherms and mechanical properties of blends of sulfonated PEEK and substituted PPSU. Chem. Mater. 2008, 20, 4327-4334. [CrossRef]

26. Di Vona, M.L.; Marani, D.; D’Ottavi, C.; Trombetta, M.; Traversa, E.; Beaurroies, I.; Knauth, P.; Lioccia, S. A simple new route to covalent organic/inorganic hybrid proton exchange polymer membranes. Chem. Mater. 2006, 18, 69-75. [CrossRef] 
27. Harrison, W.L.; Hickner, M.; Kim, Y.S.; McGrath, J.E. Poly(Arylene Ether Sulfone) Copolymers and Related Systems from Disulfonated Monomer Building Blocks: Synthesis, Characterization, and Performance-A Topical Review. Fuel Cells 2005, 5, 201-212. [CrossRef]

28. Xing, D.M.; Yi, B.L.; Liu, F.Q.; Fu, Y.Z.; Zhang, H.M. Characterization of sulfonated poly(etheretherketone)/polytetrafluoroethylene composite membranes for fuel cell applications. Fuel Cells 2005, 5, 406-411. [CrossRef]

29. Xing, P.; Robertson, G.P.; Guiver, M.D.; Mikhailenko, S.D.; Wang, K.; Kaliaguine, S. Synthesis and characterization of sulfonated poly(etheretherketone) for proton exchange membranes. J. Membr. Sci. 2004, 229, 95-106. [CrossRef]

30. Mikhailenko, S.D.; Wang, K.; Kaliaguine, S.; Xing, P.; Robertson, G.P.; Guiver, M.D. Proton conducting membranes based on cross-linked sulfonated poly(etheretherketone) (SPEEK). J. Membr. Sci. 2004, 233, 93-99. [CrossRef]

31. Li, L.; Zhang, J.; Wang, Y. Sulfonated poly(etheretherketon) membranes for direct methanol fuel cell. J. Membr. Sci. 2003, 226, 159-167. [CrossRef]

32. Feng, S.; Pang, J.; Yu, X.; Wang, G.; Manthiram, A. High-Performance Semicrystalline Poly(ether ketone)-Based Proton Exchange Membrane. ACS Appl. Mater. Interfaces 2017, 9, 24527-24537. [CrossRef] [PubMed]

33. Ding, X.; Liu, Z.; Hua, M.; Kang, T.; Li, X.; Zhang, Y. Poly(ethylene glycol) crosslinked sulfonated polysulfone composite membranes for forward osmosis. J. Appl. Polym. Sci. 2016, 133, 1-8. [CrossRef]

34. Yu, J.; Dong, C.; Liu, J.; Li, C.; Fang, J.; Guan, R. Crosslinked sulfonated poly (bis-A)-sulfones as proton exchange membrane for PEM fuel cell application. J. Mater. Sci. 2010, 45, 1017-1024. [CrossRef]

35. Lafitte, B.; Karlsson, L.E.; Jannasch, P. Sulfophenylation of Polysulfones for Proton-Conducting Fuel Cell Membranes. Macromol. Rapid Commun. 2002, 23, 896-900. [CrossRef]

36. Lufrano, F.; Gatto, I.; Staiti, P.; Antonucci, V.; Passalacqua, E. Sulfonated polysulfone ionomer membranes for fuel cells. Solid State Ionics 2001, 145, 47-51. [CrossRef]

37. Kerres, J. Development of ionomer membranes for fuel cells. J. Membr. Sci. 2001, 185, 3-27. [CrossRef]

38. Lufrano, F.; Squadrito, G.; Patti, A.; Passalacqua, E. Sulfonated polysulfone as promising membranes for polymer electrolyte fuel cells. J. Appl. Polym. Sci. 2000, 77, 1250-1257. [CrossRef]

39. Schuster, M.; Kreuer, K.-D.; Andersen, H.T.; Maier, J. Sulfonated Poly(phenylene sulfone) Polymers as Hydrolytically and Thermooxidatively Stable Proton Conducting Ionomers. Macromolecules 2007, 40, 598-607. [CrossRef]

40. Miyake, J.; Taki, R.; Mochizuki, T.; Shimizu, R.; Akiyama, R.; Uchida, M.; Miyatake, K. Design of flexible polyphenylene proton-conducting membrane for next-generation fuel cells. Sci. Adv. 2017, 3, eaao0476. [CrossRef]

41. Donnadio, A.; Casciola, M.; Di Vona, M.L.; Tamilvanan, M. Conductivity and hydration of sulfonated polyethersulfone in the range $70-120^{\circ} \mathrm{C}$ : Effect of temperature and relative humidity cycling. J. Power Sources 2012, 205, 145-150. [CrossRef]

42. Kim, J.-D.; Donnadio, A.; Jun, M.-S.; Di Vona, M.L. Crosslinked SPES-SPPSU membranes for high temperature PEMFCs. Int. J. Hydrog. Energy 2013, 38, 1517-1523. [CrossRef]

43. Yin, Y.; Suto, Y.; Sakabe, T.; Chen, S.; Hayashi, S.; Mishima, T.; Yamada, O.; Tanaka, K.; Kita, H.; Okamoto, K.-I. Water Stability of Sulfonated Polyimide Membranes. Macromolecules 2006, 39, 1189-1198. [CrossRef]

44. Asano, N.; Aoki, M.; Suzuki, S.; Miyatake, K.; Uchida, H.; Watanabe, M. Aliphatic/Aromatic Polyimide Ionomers as a Proton Conductive Membrane for Fuel Cell Applications. J. Am. Chem. Soc. 2006, 128, 1762-1769. [CrossRef] [PubMed]

45. Aoki, M.; Asano, N.; Miyatake, K.; Uchida, H.; Watanabe, M. Durability of Sulfonated Polyimide Membrane Evaluated by Long-Term Polymer Electrolyte Fuel Cell Operation. J. Electrochem. Soc. 2006, 153, A1154-A1158. [CrossRef]

46. Wu, D.; Wu, L.; Woo, J.-J.; Yun, S.-H.; Seo, S.-J.; Xu, T.; Moon, S.-H. A simple heat treatment to prepare covalently crosslinked membranes from sulfonated poly(2,6-dimethyl-1,4-phenylene oxide) for application in fuel cells. J. Membr. Sci. 2010, 348, 167-173. [CrossRef]

47. Robert, F.S.; Litt, M.H. Proton Conducting Polymers Used as Membranes. US Patent Number 5525436, 11 June 1996. 
48. Kerres, J.; Ullrich, A.; Meier, F.; Häring, T. Synthesis and characterization of novel acid—base polymer blends for application in membrane fuel cells. Solid State Ionics 1999, 125, 243-249. [CrossRef]

49. Lee, H.-F.; Killer, M.; Britton, B.; Wu, Y.; Nguyen, H.-D.; Iojoiu, C.; Holdcroft, S. Fuel Cell Catalyst Layers and Membrane-Electrode Assemblies Containing Multiblock Poly(arylene ether sulfones) Bearing Perfluorosulfonic Acid Side Chains. J. Electrochem. Soc. 2018, 165, F891-F897. [CrossRef]

(C) 2020 by the authors. Licensee MDPI, Basel, Switzerland. This article is an open access article distributed under the terms and conditions of the Creative Commons Attribution (CC BY) license (http://creativecommons.org/licenses/by/4.0/). 